\title{
Prejudice and paranoia: a comparative study of antisemitism and Sinophobia in turn-of-the-century Britain
}

Article

Accepted Version

Renshaw, D. (2016) Prejudice and paranoia: a comparative study of antisemitism and Sinophobia in turn-of-the-century Britain. Patterns of Prejudice, 50 (1). pp. 38-60. ISSN 14617331 doi: https://doi.org/10.1080/0031322X.2015.1127646 Available at https://centaur.reading.ac.uk/74439/

It is advisable to refer to the publisher's version if you intend to cite from the work. See Guidance on citing.

To link to this article DOI: http://dx.doi.org/10.1080/0031322X.2015.1127646

Publisher: Taylor and Francis

All outputs in CentAUR are protected by Intellectual Property Rights law, including copyright law. Copyright and IPR is retained by the creators or other copyright holders. Terms and conditions for use of this material are defined in the End User Agreement.

$\underline{\text { www.reading.ac.uk/centaur }}$

\section{CentAUR}


Central Archive at the University of Reading

Reading's research outputs online 


\section{Prejudice and paranoia: a comparative study of anti-Semitism and Sinophobia in turn- of-the-century Britain}

Abstract

In this article the author examines in comparative terms two of the most virulent manifestations of racial prejudice in early twentieth century British society. The language of anti-Semitism and Sinophobia in the Edwardian period and the years preceding the First World War is examined, and the similarities and differences in the ways that these two forms of prejudice were articulated, and the overlap between them, is discussed. Five strands of anti-Jewish and anti-Chinese sentiment and action are discussed. Firstly, manifestations of antiSemitism and Sinophobia in an international context, the suspicion aimed at Jews and Chinese as transnational diasporic communities, and how perceptions of these minorities, through international events such as the Russian pogroms, the Boxer Rebellion in China and the post-Boer War economic situation in South Africa, were framed in narratives of victimhood and aggression. Secondly, the transnational and colonial circuits of racialised discourse, and the relationship between periphery and hub, are considered, as are divergences in the articulation of anti-Jewish and anti-Chinese prejudice. Thirdly, the use of the language of 'invasion', used by both the political right and the left, in discussing Jewish and Chinese immigration and economic activity in Britain, with Chinese employment in British industries (in this period particular as sailors on British ships) framed in the context of a demographic 'Asiatic' takeover of European societies. Fourthly, the intersection of racial prejudice and sexual and social angst is discussed, the visceral association of immigrant groups with dirt and disease, and the sexual threat that racist and anti-Semitic literature attributed to Jews and Chinese. Finally, physical manifestations of anti-Semitism and Sinophobia in the period, the racial violence that occurred in Cardiff and Tredegar in 1911, will be described and placed in context. The article locates Edwardian antiSemitism and Sinophobia in a transitory stage in the evolution of British racism, a bridge between the separate domestic and colonial forms of prejudice present in late-Victorian discourse and new manifestations of racism, located in British cities and ports, but aimed against non-white minorities, that emerged in the inter-war period.

\section{Keywords}

\section{Edwardian, anti-Semitism, Sinophobia, Racism, Diasporas, Chinese Slavery, Immigration, Joseph Banister, Violence}

\section{Introduction}

In the late -Victorian and Edwardian periods, British society defined itself and its place in the world primarily through a series of oppositions, and the designation of the role of 'other' to certain strata of society and 'outsider' groups when compared with the mainstream. These oppositions manifested themselves in a number of different forms - 'white' as opposed to 'black', male as opposed to female, country against city, 'respectable' against 'criminal' or 'vicious'. 1 These oppositions constituted a central component of what has been described by John M. MacKenzie as an 'ideological cluster' of beliefs and values centred on the justification for and expansion of the British Empire abroad and a stratified class system at

\footnotetext{
${ }^{1}$ See Laura Tabili, “We ask for British Justice”: Workers and Racial Difference in Late Imperial Britain (London: Cornell University Press 1994) for detailed discussion of the construction in the pre and inter-war years of racial difference and 'blackness' as a political label.
} 
home. ${ }^{2}$ Of the numerous oppositions at work, none were more potent than that between rulers and ruled, between the small class of administrators at work in the Indian and African colonies, and the populations they governed. Colonialism, combined with social Darwinism, had by the last quarter of the nineteenth century led to the construction of a complex racial hierarchy, with the 'Anglo-Saxon' 'races' at the apex. ${ }^{3}$ 'Race' and definitions of racial difference and superiority came to form what amounted to a widely-held and popular belief system, old prejudices seemingly backed up by the promises of modern science. Douglas A. Lorimer writes of the emergence in the mid-nineteenth century of a 'new ideology of racism, which declared that moral and intellectual as well as physical traits were biologically determined... and gave 'race' an all-inclusive meaning so that it became, in the minds of its exponents, the most significant determinant of man's past, present and future.' ${ }^{4}$

The racial prejudice directed against colonial peoples formed one strand of Victorian racism. Parallel to this was an equally virulent manifestation of prejudice, one that combined both racial discrimination and religious paranoia, and that was aimed at a 'white' ethnic group. This was the anti-Irish sentiment that persisted throughout the nineteenth century, and which tied into the earlier primarily religious prejudices of earlier times. Anti-Irish bigotry too had an important colonial aspect, but was primarily what could be termed a 'domestic' form of prejudice, aimed at the Irish communities that had settled in the poorest and most deprived areas of the major towns and cities of mainland Britain. Anti-Irish prejudice was given an added potency by sectarianism, but the language used utilized the stereotypes that already had been employed in defining the 'difference' of the British underclass - inebriation, lack of sanitation and hygiene, an inherent predisposition towards violence etc. ${ }^{5}$

However, there were ethnic 'others' present in late-Victorian and Edwardian racial discourses that did not fit so neatly into the dichotomy of 'colonial' and 'domestic' racism; lying between a prejudice framed in an explicitly foreign, abstract and exotic context, based on colonial conflict and conquest, and another that manifested itself in British inner cities. This article will discuss in comparative terms the prejudice aimed against two diasporic groups: the Chinese population, mainly resident in the major ports of the country, and the larger

\footnotetext{
${ }^{2}$ John M. MacKenzie, Propaganda and Empire: The manipulation of British public opinion (Manchester: Manchester University Press 1988), 2

${ }^{3}$ Panikos Panayi, Immigration, Ethnicity and Racism in Britain 1815-1945 (Manchester: Manchester University Press 1994), 131

${ }^{4}$ Douglas A. Lorimer, Colour, Class and the Victorians (Bristol: Leicester University Press 1978), 14

${ }^{5}$ See L. Curtis, Apes and Angels: The Irishman in Victorian Caricature (Devon: David \& Charles Ltd. 1971) for discussion of nineteenth century popular depictions of the 'Irish gorilla' and the 'Irish Frankenstein'
} 
Jewish community, which had grown rapidly in the last quarter of the nineteenth century following the wave of migration in response to the pogroms of the early 1880 s. In comparing and contrasting anti-Semitism and Sinophobia in the Edwardian period and the years immediately after, this article will reflect on the evolution of racial prejudice and the role of the 'other' in the Edwardian period and beyond. The place of both of Jews and Chinese in the racial hierarchy constructed during the nineteenth century was unclear, with a conditional 'whiteness' sometimes extended to immigrant Jewry and sometimes withheld, a status from which Chinese migrants were wholly excluded. ${ }^{6}$ But, if excluded from 'whiteness', neither community neatly fitted the template of the colonial 'other' either. Both communities were depicted on some intrinsic level as fundamentally alien to British society, culture and the body politic, as with colonial peoples, but they were also resident in British towns and cities, whether temporarily or permanently, and interacting on a day to day basis with their English, Welsh or Irish neighbours. The nature of these interactions would form a central part in the expression of both anti-Semitism and Sinophobia in the Edwardian metropolis. Both Jews and Chinese were 'visible' minorities, easily identifiable, and both made up a small part of wider global diasporas (The King of Siam, in reference to the diasporic nature of Chinese communities, labelled them the 'Jews of the East.' $)^{7}$. Nevertheless, there were also important distinctions in the way in that the 'racial' 'difference' of the two groups was articulated, which will be dissected in this article.

This article will discuss how anti-Jewish and anti-Chinese prejudice manifested itself politically, in the rhetoric of Tories, Liberals and socialists, socially, and finally in its ultimate expression in physical violence against these communities, rioting that reflected a deeper Edwardian malaise. The article will argue that the Edwardian period marked a key transitional period in British racism, the beginnings of the conflation of 'colonial' and 'domestic' forms of racial prejudice that would take shape in the inter-war years.

\footnotetext{
${ }^{6}$ See Lucien Wolf, 'The Zionist Peril', The Jewish Quarterly Review, vol. 17, no. 1, 1904, 1-25 (7-8) - 'The Jews are certainly not as unassimilable as the Black and Yellow races, for the simple reason that nature has made them white men...' and Eitan Bar-Yosef and Nadia Valman, 'Introduction Between the East End and East Africa: Rethinking Images of 'the Jew' in Late-Victorian and Edwardian Culture' in Eitan Bar-Yosef and Nadia Valman (eds), 'The Jew' in Late-Victorian and Edwardian Culture: Between the East End and East Africa (Basingstoke: Palgrave Macmillan 2009) for discussion of Judaism and 'conditional whiteness'.

${ }^{7}$ Lynn Pan, Sons of the Yellow Emperor: The story of the overseas Chinese, (London: Martin Secker and Warburg Ltd 1990) 129
} 


\section{Victims and 'puppet-masters': anti-Semitism and Sinophobia on an international level}

As diasporic minorities, the ways in which the Jewish and Chinese communities were depicted in the popular press and in public discourse during the Edwardian period were closely bound up with how Jews and Chinese were portrayed on an international level. The diasporic nature of international Jewish and Chinese settlement conferred a peculiar combination of strength and vulnerability. The obvious weakness of small, often isolated and politically disenfranchised communities was tempered by a widespread suspicion of networks and connections that crossed national boundaries, fuelling suspicions of international intrigue and influence. The 'International Jew', the financier exerting power over monarchs and heads of state, was a potent stock in trade for anti-Semites of both the Left and Right. The 'Jew' as a transnational figure could be blamed, depending on the inclination of the writer, for international capitalism or socialism, to be behind a war or subverting the war effort. 'The Rothschild leeches have for years hung on with distended suckers to the body politic of Europe... wherever rumours of war circulate... you may be sure that a hook-nosed Rothschild is at his games somewhere near the region of disturbance.' ${ }^{8}$ The international nature of Chinese migration, with communities established in the United States and areas of the British Empire as well as British cities, also lent itself to conspiracy theories, that the trades in narcotics and people that the Chinese migrants were widely believed to be engaged in must be directed by some central, all-powerful mastermind, a 'Chinese Moriarty', whether the Fu Manchu of Sax Rohmer's novels, the Wu Ling of the Sexton Blake stories, or any number of other Chinese 'godfathers' in early twentieth century pulp fiction. Rohmer, writing about the Chinese kinship networks he encountered in Limehouse, speculated, 'Supposing... a number of those sinister organisations - were in turn responsible to the direction of some super-society. Such a society would hold the power to upset governments, perhaps change the very course of civilisation." Aside from the belief in these sinister 'puppeteers' that formed so central a part of Edwardian anti-Semitism and Sinophobia, Jews and Chinese were generally portrayed as either passive victims of oppression or propagators of oppression themselves, with little middle ground. The first part of this article will discuss three international cases in the early Edwardian period in which narratives of Jewish and Chinese

\footnotetext{
${ }^{8}$ The Labour Leader, quoted in Colin Holmes, Anti-Semitism in British Society, 1876-1939, (London: Edward Arnold Publishers Ltd. 1979) 83

9 Jenny Clegg, Fu Manchu and the 'Yellow Peril': The Making of a Racist Myth, (Stoke-on-Trent: Trentham Books Ltd. 1994), 3-4; See also Gregor Benton and Edmund Terence Gomez, The Chinese in Britain, 1800 Present: Economy, Transnationalism, Identity, (Basingstoke: Palgrave Macmillan 2011) 299
} 
victimhood and aggression were played out: the Russian pogroms, the Boxer Rebellion, and in South Africa after the conclusion of the Boer War.

The sporadic anti-Jewish persecutions in Tsarist Russia from the early 1880s onwards had garnered widespread condemnation and denunciations from across the British political spectrum. The pogroms, coupled with the fallout from the Dreyfus Affair across the channel, to an extent attached a 'disreputability', in John A. Garrard's words, to explicit anti-Semitism at the turn of the twentieth century, and the anti-Jewish riots and massacres were met with large outdoor protests in London and other urban areas, whilst a rally in support of Dreyfus and Emile Zola in Hyde Park attracted some 15,000 people. ${ }^{10}$ A range of establishment figures issued public protests, in speeches and in print, at the actions of the Russian government. The Kishinev pogrom of April 1903, although only the latest in a long series of outrages, shocked popular opinion in Europe and America, with the atrocities committed presented in the press in horrific detail. Kishinev served to fix a particular image of passive victimhood on the Jews of Eastern Europe, and, by extension, those immigrants who had left the Pale of Settlement and settled in British urban areas, the image of the Jewish refugee, buffeted by forces beyond his or her control. Jewish socialist and nationalist groups, both in Russia and amongst the diaspora, sought to challenge this supposed passivity. ${ }^{11}$ The Jewish worker as passive victim also informed images of immigrant Jewry settled in Britain; the Jewish 'greener' subsisting on a pittance in an East End sweatshop, tyrannised by their employer, an image capitalised on both by sympathetic labour organisations and anti-alien campaigners.

However, within the response to the anti-Jewish persecutions of the late nineteenth and early twentieth century was a strand of opinion that laid the blame, partly or wholly, on the Eastern European Jews themselves. W.H Wilkins, the anti-immigrant campaigner, wrote in 1892:

With an imperfect knowledge of the facts we are hardly in a position to judge of the action which the Russian government has seen fit to take against its Jewish subjects. On the surface it certainly appears that a great wrong has been done... but we must remember that we have not yet heard what there is to be urged on the other side. We can scarcely be expected to credit without adequate proof all the heresay tales of Russian oppression. Isolated instances do not suffice... It is

\footnotetext{
${ }^{10}$ John A. Garrard, The English and Immigration 1880-1910, (London: Oxford University Press 1971) 16-17

${ }^{11}$ M.N Penkower, 'The Kishinev Pogrom of 1903: A Turning Point in Jewish History', Modern Judaism, vol. 24, no.3, October 2004, 187-225
} 
said... that the system of usury and extortion practiced by many of the Russian Jews upon the peasantry has, in large measure, tended to bring about the present state of things. ${ }^{12}$

Arnold White, writing seven years later, framed the legal discrimination and physical violence of the Russian government as a matter of national survival. If Russian Jews were emancipated, White wrote, 'Russians would have no chance of survival against the cold determination of a people that exists only when living as a parasitic growth on another race. What Tsar in his sense, what sane Russian Minister would permit his country to commit suicide by ceding the civil administration to a Jewish minority?' ${ }^{13}$ White's vision of a Jewish 'takeover' fed into the popular anti-Semitic trope post-1917 that the Bolshevik Revolution had been in effect a Jewish 'coup', part of a world-wide conspiracy, that a Jewish 'clique' was subjugating the Russian people. ${ }^{14}$ The Russian persecutions were thus framed, not only in terms of Jewish victimhood, but also in terms of Jewish aggression, the classic image of the Jew as money-lender, the Jews as a 'parasitic growth', by implication not only on the Russian but on the British people as well.

The portrayal of the international Chinese diaspora in the popular press also oscillated between the roles of passive victim and violent protagonist. China occupied a difficult position in the pantheon of late-Victorian/Edwardian 'others'. Non-white, technologically inferior, and the loser in a series of nineteenth century wars with the European powers and Japan, China had still resisted significant territorial encroachment by the colonial powers. China was viewed with a mixture of contempt and fascination, a power waning perhaps, but still a power none the less. As Milligan writes, '... the Celestial was easy to see as a rival to the growing British Empire... China boasted... a huge population and a culture that seemed to have persisted largely unchanged for thousands of years... ${ }^{15}$ The violence, directed against both Europeans and Chinese Christians, that broke out in the summer of 1900 radically altered the popular perception of the Chinese, from the passive, decadent, opiumaddled figure of nineteenth century theatre and literature to the more familiar (colonial) image of the 'savage', a physical threat to western civilisation, the killer of women, children

\footnotetext{
${ }^{12}$ W.H Wilkins, The Alien Invasion, (London: Methuen and Co. 1892), 11

${ }^{13}$ Arnold White, The Modern Jew, (London: William Heinemann 1899), 39-40

${ }^{14}$ See Hilaire Belloc, The Jews, (London: Constable \& Company, Ltd. 1922), 58: 'all those leaders [of the Bolshevik movement] without exception, were Jews... and all that followed was done directly under the order of Jews.'

${ }^{15}$ Barry Milligan, Pleasures and Pains: Opium and the Orient in Nineteenth-Century British Culture, (Charlottesville: University Press of Virginia 1995) 84-85
} 
and missionaries, to be put down by armed intervention. Harold Isaacs discusses the press depictions of the Chinese at the point, describing in salacious detail 'the descent of Boxer fanatics on foreign and Chinese Christians, of brutal killings and tortures, among them the celebrated 'torture of a thousand cuts'. ${ }^{16}$ Chen describes the Boxer Uprising as a 'pivotal event' in the formation of the Yellow Peril paranoia that so informed Sinophobic perceptions of the Chinese, in China and amongst the migrant diaspora. ${ }^{17}$ The transition of the 'Orient' from a source of contempt and illicit pleasures to a potential contemporary or future threat was intensified by the Japanese victory in the Russo-Japanese War. A possible alliance between the two East Asian empires, and some future attack on the West, formed a key part of anti-Chinese racial paranoia. ${ }^{18}$ This is the scenario that was envisaged by the American author Jack London in his 1910 novella The Unparalleled Invasion. Set in 1976, London describes a future apocalyptic racial conflict, which begins with a Sino-Japanese alliance and unchecked Chinese migration to the West:

First came the Chinese immigration (or rather, it was already there, having come there slowly and insidiously during the preceding years). Next came the clash of arms and the brushing away of all opposition by a monster army of militia soldiers, followed by their families and household baggage. And finally came their settling down as colonists in the conquered territory. Never was there so strange and effective a method of world-conquest. ${ }^{19}$

The novella ends with a campaign by the 'West' of biological warfare and genocide against the Chinese, all described by London in ghoulish detail. Perceptions of China's international role began to change after the Revolution of 1911, and the modernisation that followed. But the Edwardian period was replete with popular fiction envisaging a Chinese attack on Britain in particular, or on the West generally. In the invasion literature that flourished in the decade before the First World War, the 'Dowager Empress' of Peking was a popular antagonist.

\footnotetext{
${ }^{16}$ Shih-Wen Chen, Representations of China in British Children's Fiction, 1851-1911, (Farnham, Surrey: Ashgate Publishing Limited 2013) 151

${ }^{17}$ Chen, Representations of China in British Children's Fiction, 157

${ }^{18}$ Ross G. Forman, China and the Victorian Imagination: Empires Entwined, (Cambridge: Cambridge University Press 2013) 128-129

${ }^{19}$ Jack London, 'The Unparalleled Invasion , Excerpt from Walt Nervin's "Certain Essays in History", in I.F Clarke (ed.) The Tale of the Next Great War, 1871-1914: Fictions of Future Warfare and of Battles Still-tocome, (Liverpool: Liverpool University Press 1995) 263
} 
If in this genre, replete with paranoia and hyper-nationalism, the 'Asiatic' was an external threat, the 'cosmopolitan Jew' was a dangerous internal subversive force. The popular writer William Le Queux, given to fantasising about London pogroms and foreign invasions, claimed that European Jewry owed its loyalty to Germany: 'the Jews have worked for the triumph of the Teuton everywhere', and Jewish assistance towards foreign enemies was a staple of this type of fiction. ${ }^{20}$ The fears of external conquest by a military enemy merged smoothly with anti-immigrant sentiment. Both anti-Semitic and Sinophobic campaigners utilised this language of invasion in relation to immigration, in the Empire and in the imperial hub.

One area where narratives of Chinese victimhood and the trope of the malign influence of 'Jewish finance' intersected was in the 'Chinese slavery' controversy that played its part in the 1906 General Election, and in which the language of both anti-Semitism and Sinophobia were used by Conservatives, Liberals and the labour movement. The Boer War had been condemned by elements of the Liberal Party and the labour movement as a 'Jews War', motivated by Jewish financial interests in South Africa. ${ }^{21}$ Elements of the socialist movement that took the lead in denouncing the Kishinev pogrom could nevertheless fall into the use of anti-Semitic imagery when discussing the economic situation in South Africa. In the introduction to a book constituting a condemnation of Kishinev, the Irish nationalist and socialist Michael Davitt makes this explicit:

Where anti-Semitism stands... against the engineers of a sordid war in South Africa, or as the assailant of the economic evils of unscrupulous capitalism anywhere, I am resolutely in line with its spirit and programme. Where however, it only speaks and acts in a cowardly racial warfare [as in Kishinev]... it becomes a thing deserving of no more toleration from right-minded men than do the germs of some malady laden with the poison of a malignant disease. ${ }^{22}$

After the conclusion of the war, the conditions of both the African workforce and that of Chinese indentured labour were blamed in some socialist circles on the avarice of Jewish mine-bosses. These attacks, when emanating from the political Left, were frequently couched

\footnotetext{
${ }^{20}$ The Jewish Chronicle 17 March 1911. See also David Glover, Literature, Immigration, and Diaspora in Finde-Siècle England: A Cultural History of the 1905 Aliens Act, (Cambridge: Cambridge University Press 2012) for detailed discussion of the intersection between anti-Semitism and the 'invasion' genre of fiction.

${ }^{21}$ Panayi, Immigration, Ethnicity and Racism in Britain, 116

${ }^{22}$ Michael Davitt, Within the Pale: The True Story of Anti-Semitic Persecutions in Russia, (London: Hurst and Blackett Ltd 1903), viii-X
} 
in the language of anti-colonialism. In one such pamphlet entitled Bondage for Black, Slavery for Yellow Labour, the MP John Burns made explicit references to Chinese history and that of the Jewish diaspora, and the legacy of oppression:

The tragic irony of all this iniquity is that the financial Jew whose race has been the slave of the centuries, the persecuted of all countries, the hunted of all time, should be the central operating figure in reviving servitude, and voluntarily and gratuitously allow his vain and vulgar cupidity to enthral a race of men who were a great and civilised race when the Chosen People of Israel were in Egyptian bondage... 23

Burns, in a reference to The Merchant of Venice, writes of a 'syndicate of mine owners... [feeding on] their coveted compound of Chinese flesh', of a plot 'to make the Transvaal a great Kimberley compound where blacks and coolies will earn huge dividends for the Jews. There will be no room for white men in the Transvaal if they succeed. ${ }^{24}$

However, although sometimes framed in the language of anti-colonialism and human rights, the popular outcry against 'Chinese slavery', as Grant and others have written, was not so much motivated by concern for working conditions for indentured Chinese labour in South African mines, but by the economic threat to English and Afrikaner. ${ }^{25}$ The campaigns against Chinese 'slavery' in South Africa and for immigration restrictions in the United Kingdom, the former with an impetus springing from the Liberal and Labour parties, the latter being pushed forward by the Conservatives, in fact made use of much of the same language, of the 'other' as an economic and social threat to domestic workforces, once more employing the imagery of invasion and illustrating the overlap in currents of racist discourse in both the colonies and the metropolis.

\section{The imperial context and divergences}

The 'Chinese slavery' controversy and the language used in describing the interactions between the Jewish and Chinese diasporas employed by John Burns illustrates the importance of the imperial and transnational contexts in which both anti-Semitic and Sinophobic language was framed, and the colonial circuits through which racialised discourse flowed.

\footnotetext{
${ }^{23}$ John Burns, Bondage for Black, Slavery for Yellow Labour, (London: Kent and Matthews Ltd. 1904), 2

${ }^{24}$ Burns, Bondage for Black, Slavery for Yellow Labour, 3-4

${ }^{25}$ Kevin Grant, A Civilised Savagery: Britain and the New Slaveries in Africa, 1884-1926, (New York:

Routledge 2005), 82-83, 105
} 
This article posits that popularly-expressed anti-Jewish and anti-Chinese sentiment in the Edwardian period formed a transitional stage in the evolution of racial prejudice, an increased conflation between a 'bread and butter' domestic racism and an 'exotic', abstract colonial prejudice. Nevertheless, the boundaries between these two forms of racism were porous and overlapping at times, and in particular the discourse of Sinophobia as articulated in a British domestic context was shaped by the colonial experience, in Australia, South Africa and the Pacific coast of North America. The tropes of 'invasion' that portrayed Britain as vulnerable to occupation or 'reverse-colonisation' by 'Asiatics' or 'Celestials' in the first decade of the twentieth century had been formulated in an Australian, Canadian and American context from the 1870 s onwards, germinating in the colonial periphery rather than the imperial centre. Charles H. Pearson's 1894 treatise on race and racial competition, National Life and Character, pays a great deal of attention to the current Chinese 'threat' to British colonial possessions, as well as a potential future menace to the British Isles themselves. Pearson writes that: 'No one in California or Australia, where the effects of Chinese competition have been freely studied, has, I believe, the smallest doubt that Chinese labourers, if allowed to come in freely, could starve all the white men in either country out of it, or force them to submit to harder work and a much lower standard of wages. ${ }^{26}$ Pearson explicitly compares Jewish and Chinese migrants (having earlier discussed Jewish fecundity), suggesting that the Chinese were 'Flexible as Jews... more versatile even than Jews, they are excellent labourers, and not without merit as soldiers and sailors [with] a capacity for trade. ${ }^{27}$

Rudi Batzell has demonstrated how the Californian labour movement in its anti-Chinese immigration campaign of the 1870s drew on the imagery and rhetoric of the abolitionist movement of the $1860 \mathrm{~s}^{28}$ The domestic debates on 'Chinese slavery' that reached their height in the 1906 General Election also drew significantly on the British anti-slavery rhetoric of the first half of the nineteenth century, both in language and imagery. The uncertain position of the Chinese labourer as both victim and potential threat in this controversy, discussed above, was also apparent in contemporary Sinophobic sexual angst, also framed in a transnational and imperial context, whether in terms of sexual slavery in California or homosexual rape in South Africa. ${ }^{29}$ Those campaigners voicing dire warnings

\footnotetext{
${ }^{26}$ Charles H. Pearson, National Life and Character: A Forecast, (London: Macmillan and Co. 1894) 132.

${ }^{27}$ Pearson, National Life and Character, 118.

${ }^{28}$ Rudi Batzell, 'Free Labour, Capitalism and the Anti-Slavery Origins of Chinese Exclusion in California in the 1870s', Past and Present, no. 225, November 2014, 143-186 (185-186).

${ }^{29}$ See Charles Frederick Holder, 'Chinese Slavery in America' The North American Review, vol. 165, no.490, September 1897, 288-294; Gary Kynoch, "'Your Petitioners are in Mortal Terror": The Violent World of
} 
over current Jewish and future Chinese migration to Britain pointed to the experiences of white settler populations on the periphery; that just as the racial future of the colonies was threatened demographically by Chinese mass migration, so in due course the imperial metropolis itself would be in danger of so-called 'reverse colonisation', Chinese or Jewish. If the Transvaal or New South Wales today, so the narrative ran, why not Limehouse, Whitechapel or Tiger Bay tomorrow? In 1908 the trade unionist Havelock Wilson claimed that 'the [racial] trouble is not local, but universal, and that, of course, only increases the peril. ${ }^{30}$ As Sascha Auerbach writes: 'Many of the issues that came to dominate metropolitan race relations first rose to prominence in the empire.' ${ }^{31}$

As mass Jewish migration transformed British inner-cities from the 1880s onwards, and more modest Chinese settlement took place in dockland areas of Britain, Sinophobia and antiSemitism increasingly blurred the borders between forms of domestic and externally-focused racial prejudice, combining the tropes and imagery of both. Nevertheless, there are important divergences between contemporary racial categorisation of the two minority groups. In many respects the locating of Jews within racial hierarchies or structures involved an ambiguity not present in the Chinese case. The complexities of what exactly constituted 'Jewishness' - the interplay of religion, culture, ethnicity, tradition and location - were not present in the rather straight-forward racial classification of the Chinese. Was the Jewish migrant 'white' or 'black', or somewhere between the two binary oppositions? Brian Cheyette has, in a literary and cultural context, discussed at length the uncertain position of Jewish identity in nineteenth and twentieth century liberal British society. "'The Jew", like all doubles, is inherently ambivalent... Unlike marginalised 'colonial subjects' who were for the most part, confined racially to the 'colonies' in the late nineteenth century, Jews were, simultaneously, as the centre of European metropolitan society and, at the same time, banished from its privileged sphere..., 32 The Jewish arrival, by virtue of skin colour, could potentially 'pass' as a Gentile in wider society in a way that the Chinese migrant could not, a factor that only increased the potency and angst of turn-of-the-century anti-Semitism, the apparent 'whiteness' of 'the Jew', acting as a 'camouflage'. There was also the possibility of Jews

Chinese Mineworkers in South Africa, 1904-1910', Journal of Southern African Studies, vol. 31, no.3 September 2005, 531-546 (538).

${ }^{30}$ Sascha Auerbach, Race, Law and "The Chinese Puzzle" in Imperial Britain, (New York: Palgrave Macmillan 2009) 39.

${ }^{31}$ Auerbach, Race, Law and "The Chinese Puzzle" in Imperial Britain, 3.

32 Bryan Cheyette, Constructions of 'The Jew' in English Literature and Society: Racial Representations, 1875 1945, (Cambridge: Cambridge University Press 1993) 12. 
converting to Christianity and their subsequent status, again raising the question of whether 'Jewishness' was primarily ethnic or religious.

The placing of the Chinese within a Victorian/Edwardian racial pyramid on the other hand, and the racialised discourse of the 'yellow peril' that grew out of it, was relatively uncontroversial. The Comte De Gobineau's influential Essay on the Inequality of the Human Races, written between 1853 and 1855, claimed that humanity '... naturally divided into three... the white, the black and the yellow... ${ }^{33}$ Within the 'white' group Gobineau included 'those races which are also called Caucasian, Semitic or Japhetic. ${ }^{34}$ On the 'yellow' races, Gobineau wrote that:

The yellow man has little physical energy, and is inclined to apathy, he commits none of the strange excesses so common among the Negroes... The yellow races are thus clearly superior to the black. Every founder of a civilisation would wish the backbone of his society... But no civilised society could be created by them; they could not supply its nerve force, or set in motion the springs of beauty and action. ${ }^{35}$

This categorisation, of the 'yellow' races existing at some point between 'white' and 'black', not colonial 'natives' but existing below 'white' 'civilisation' (whilst still able to mount an apocalyptically-framed challenge to that civilisation in the context of the 'yellow peril') informed Pearson's 1894 treatise on racial difference, and indeed the articulation of Sinophobia into the twentieth century.

Another distinction was socio-economic. The Jewish community in Edwardian Britain was stratified in class terms - encompassing a small Jewish 'aristocracy', a solid Anglo-Jewish bourgeoisie, and an increasingly unionised proletariat - with no real equivalent in the much smaller Chinese population. Jews interacted and functioned at every social level of British society, Chinese did not. However, despite these important divergences in contemporary racial categorisation and social positon of the two groups, the language employed against both Jewish and Chinese migrants made use of the same imagery and themes - of invasion, moral subversion and economic displacement. The article will now consider the language in which these Jewish and Chinese 'threats' to economic and racial stability was articulated.

\footnotetext{
${ }^{33}$ Michael D. Biddiss (ed.), Gobineau: Selected Political Writings, (London, Jonathon Cape 1970) 109.

${ }^{34}$ Biddiss (ed.), Gobineau: Selected Political Writings, 109.

${ }^{35}$ Michael (ed.), Gobineau: Selected Political Writings, 136.
} 


\section{Immigration and the language of invasion}

Tony Kushner has located the debate on immigration and the demand for legislation to restrict entry into the United Kingdom (a first in peace time) within a wider Edwardian current of malaise and self-doubt.

Superficially it concerned increased movement into Britain (largely of East European Jews) but at a deeper level was nothing to do with the impact these 'aliens' made. Concern about the 'question of England', and especially the fitness of its people to compete internationally both militarily and commercially, tied in with national debates about national efficiency, eugenics, free or fair trade and differing party political appeals to a mass electorate... ${ }^{36}$

Indeed, by the time 'anti-alien' legislation was enacted in 1905, the great diasporic movement of Jewish populations from Eastern Europe had largely tailed off, although this year witnessed an increase in political refugees fleeing persecution following the failure of the Russian Revolution. Anti-alien sentiment was tied up with a general xenophobic paranoia about racial and social decline. The Liberal Party and the Left made much of the incongruity of a Tory policy that had overseen the importation of Chinese labour into the Transvaal, but that was passing legislation to restrict entry into Britain. A 1904 socialist pamphlet reveals the complexity of contemporary attitudes towards ethnicity generally and anti-Semitism in particular:

If you are a Chinaman you are welcome in South Africa, and if you are a millionaire you are equally welcome in Park Lane, but if you are a Jewish tailor flying from injustice and persecution, you are not welcome in England at all... The rich Jew, who has done his best to besmirch the fair name of England, and to corrupt the sweetness of our national life and character, is allowed free entrance

\footnotetext{
${ }^{36}$ Tony Kushner, Remembering Refugees: Then and Now, (Manchester: Manchester University Press 2006) 4-5
} 
to our country... while the poverty-stricken but much worthier Russian or Polish immigrant is to be chased like vermin beyond our frontiers. ${ }^{37}$

The response of Conservative electoral propaganda to these criticisms is indicative of contemporary attitudes towards both Jewish 'aliens' and 'Asiatics'. In one pamphlet entitled Chinese and Aliens - the anonymous author, writing on behalf of the Conservative Publication Department, begins by denouncing 'criminal aliens.' 'The Unionist Government wants to keep these creatures out of Great Britain. They don't want to see the honest Britisher turned out by these scourings of European slums.' The writer then lists a series of comparisons between 'Chinamen' in South Africa and 'aliens' at home. 'The Chinese have contracted... for payment in food, housing and wages; The Aliens will work for any wage, however small. They live on food almost unfit for human consumption, being frequently half starved.' 'The Chinese have residences provided, and cannot mix with other inhabitants of the colony; The Aliens will live in any dirty dwelling, herded like cattle, and will degrade and contaminate the whole neighbourhood.' 'The Chinese cannot displace the white population; The Aliens drive out the British population.' 'The Chinese will return home in the course of a few years, or as soon as they want to; The Aliens stay here, as their own country was glad to get rid of them; they increase and multiply, and displace our own people. ${ }^{38}$

Conservative literature during the 'Chinese Slavery' controversy stressed the separation between the economic situations in South Africa and Britain. The Chinese indentured labourers on the Rand could be segregated, quarantined in effect, kept from contact with 'white' society. The 'aliens' on the other hand, as the pamphlet above asserted, could not be so contained, thus the need for political legislation to restrict 'alien' entry into Britain. The core of Sinophobic political activity on the Left in the Edwardian period and immediately after, by contrast, focused on conflating the two situations, stressing that if the Chinese could be imported as cheap labour and strike-breakers in the colonies, then they could be in Britain also, conflating domestic and imperial concerns. Anti-Semitism used the language of invasion in discussing Jewish settlement in Whitechapel and Stepney; Sinophobia made use of the same themes, the prospect of inner-city areas and industrial labour being 'colonised' by a not only an 'alien' but a non-white population as well. If Whitechapel was described in

\footnotetext{
${ }^{37}$ H. Snell, 'The Foreigner in England - An Examination of the problem of Alien Immigration', 1904, pamphlet in the London School of Economics archive, ILP 5/1904/64

${ }^{38}$ Anonymous, 'Chinese and Aliens', pamphlet issued by the Conservative Publication Department, London

School of Economics archive, JF2(42C)/266
} 
anti-Semitic tracts as 'Jewtown' or London generally as 'Jerusalem-on-Thames' ${ }^{39}$ then Limehouse, or a few streets in that area of London, had from the mid-nineteenth century been labelled as 'Chinatown', along with areas in Liverpool and Cardiff. Herman Scheffauer, writing in 1911, referred to Chinese settlement in the familiar language of 'yellow peril' literature:

The tenacious Chinese dragon had made himself three comfortable lairs in three of the chief seaport cities and, true to his dragon nature, lies hidden in darkness, but fully alert. Whether Saint George the dragon-slayer is to defend himself against the growths or ravages of this fantastic monster may yet become a national problem. ${ }^{40}$

In fact, the Chinese population resident in the United Kingdom, whether from Hong Kong or mainland China, was, in numerical terms, negligible, when compared with the Jewish, Irish, or German communities settled in Britain. ${ }^{41}$ Sinophobic propaganda in the period warned of imminent Chinese settlement in British cities and ports on the scale of these other immigrant groups, or perhaps surpassing them in numbers. As early as 1878, an article in a French journal concluded by claiming 'We shall see arise in the cities of Europe Chinese quarters... and the Chinese will end by fixing [themselves] among us like the Jews. ${ }^{42}$ In a document entitled Chinese Invasion of Great Britain, A National Danger, A Call to Arms, written in 1908, the National Transport Workers Federation warned of the future consequences of shipowners employing Chinese and other 'Asiatics' rather than 'Britishers' on their ships:

If the employment of Asiatics can be justified on board British ships, competing with our own people in their own country, then justification exists for thousands of Chinese to be imported into this country to compete with the miners, railwaymen, fishermen and all other classes of shore workers. ${ }^{43}$

\footnotetext{
${ }^{39}$ David Feldman, 'The Importance of being English: Jewish immigration and the decay of liberal England' in David Feldman and Gareth Stedman Jones (eds.), Metropolis London: Histories and Representations since 1800 (Oxford: Routledge 1989) 56-84 (56); Holmes, Anti-Semitism in British Society, 28

${ }^{40}$ Herman Scheffauer, 'The Chinese in England: A Growing National Problem' in The London Magazine, June 1911

${ }^{41}$ In 1891 the Chinese-born population of England and Wales was estimated at 582. Gregor Benton and Edmund Terence Gomez, The Chinese in Britain, 51

${ }^{42}$ The Times 22 November 1878, in J.P May, 'The British Working Class and the Chinese 1870-1911: With particular reference to the Seamen' Strike of 1911', MA Thesis, University of Warwick, 1973, 1 43 'Chinese Invasion of Great Britain, a National Danger, a Call to Arms' issued by the National Transport Workers Federation, 1909, University of Warwick Modern Records Centre, MSS 75/3/14/2
} 
Chinese settlement and economic supplanting of the native workforce was portrayed in the socialist press as a Europe-wide capitalist project. In an article entitled 'Asiatic Labour For Europe', a correspondent in the Labour Leader articulated this paranoia:

Hitherto the introduction of Asiatic blackleg labour has been confined to the distant continents of America, Africa and Australia. Now there is a strenuous attempt to introduce it into Europe. The patriotic magnates of Hungary... have mooted a scheme for introducing an "army of Chinese coolies" into Hungary if the agricultural labourers of Hungary dare to strike... the Prussian magnates have decided to send for Chinese cheap labour... they regard the step "as a regrettable necessity." And necessity, of course, knows no law - moral or humane. ${ }^{44}$

The anti-Semitic writer Joseph Banister, meanwhile, laid the blame for Chinese immigration into Britain on Jewish conspirators, as part of a wider Jewish plot to undermine English racial stock. Referring to immigration generally, Banister wrote, 'If [immigration] continues it is only a matter of time when the majority of the inhabitants of London, and other large English towns, will have as much right to be described as Anglo-Saxons, as have the present mongrel inhabitants of the Hellenic Kingdom to be called Greeks'. ${ }^{45}$ In typically vitriolic language, Banister went on to claim:

The Jews not only compose the most numerous and undesirable element among our foreign invaders, but are at the head of the various movements for bringing other obnoxious aliens to this country... the attempt to introduce swarms of Chinese laundrymen into England was made by Jews, and received its support chiefly from Jews, and Jew controlled newspapers. ${ }^{46}$

Both Chinese and Jews were portrayed as enjoying an unfair economic advantage over the British workman, popularly supposed to be able to work greater hours in worse conditions for less money, what J.P May described as 'inherent economic qualities' attributed to both Jews and Chinese, and the identification of both groups generally with an unfair capitalist and exploitative social system. ${ }^{47}$ 'In the battle of populations', wrote a correspondent in the ILP

\footnotetext{
${ }^{44}$ Labour Leader, 14 December 1906

${ }^{45}$ Joseph Banister, England Under the Jews, (London: 1901) 10

${ }^{46}$ Banister, England Under the Jews, 36-37. This charge would be repeated by the fascist and biological racist Arnold Leese in the 1950s, who claimed that Jews were facilitating immigration from the Caribbean, again as part of a conspiracy against Anglo-Saxon racial stock.

${ }^{47}$ May, 'The British Working Class and the Chinese', 131
} 
News, 'it is the race which can eat least and work most that will survive.' 48 By the First World War this stereotype of the Jewish worker as both 'economic man' and inveterate strike-breaker was increasingly being directed instead against Chinese labourers and sailors, as Jewish trade unions began successfully to unionise and fight for better conditions in the sweated industries. The industrial unrest of 1911-12 might have witnessed Jewish labour and the Jewish trade union movement 'coming in from the cold' to some extent, but it was also the catalyst, during the sailors' strike, for one of the most explicitly racist campaigns to be organised by a British trade union, directed primarily against Chinese workers. ${ }^{49}$

\section{Society, sexuality and violence}

In the late-Victorian and Edwardian period particular ethnic groups were linked in antiimmigrant discourse with certain subversive and criminal activities. Both Chinese and Jews were portrayed as inveterate gamblers, and depicted as carriers of various 'foreign' diseases, with Sinophobic and anti-Semitic propaganda invariably depicting immigrants as 'dirty' and lacking in basic hygiene (a familiar stereotype, employed against other minorities such as the Irish, and indeed the very poor generally). Jews were accused of 'sharp practice' in their business dealings, and the right for Jewish traders to work on Sundays was a particular cause of grievance exploited by anti-immigrant groups such as the British Brothers League (BBL). Politically, Jewish refugees from Eastern Europe were portrayed as violent anarchists and nihilists, and career criminals. ${ }^{50}$ The Chinese resident in the large sea-ports, meanwhile, were portrayed en masse as being addicted to narcotics. Both opium and gambling, however, when indulged 'within closed doors' and within minority communities, were in themselves viewed as relatively harmless. It was popularly supposed that for the 'Celestial' opium was no more harmless than alcohol and tobacco were for the 'Britisher'. ${ }^{51}$ What drew all these strands together, and led to Chinese opium consumption in particular being viewed as a threat to 'Anglo-Saxon racial stock' and British society generally was the exposure of white women to these practices. Both Sinophobia and anti-Semitism in the early twentieth century focused to an obsessive degree on the sexual threat presented by Jews and Chinese. This sexual paranoia was heavily linked with the parallel fixation on ethnic 'others' as 'dirty' - the immigrant as a

\footnotetext{
${ }^{48}$ ILP News, February 1898

${ }^{49}$ Tabili, “We ask for British Justice” 88. Anne J. Kershen, Uniting the Tailors: Trade Unionism Among the Tailors of London and Leeds, 1870-1939 (Ilford: Frank Cass and Co. Ltd. 1995) 155-156

${ }^{50}$ Wilkins, The Alien Invasion, 47-48. See Banister, England Under the Jews, 10-11: 'There are black sheep in every flock, but of the alien sheep who flock here, about 99 per cent appear to be black. The English are not a naturally criminal race like the Jews.'

${ }^{51}$ Gomez and Benton, The Chinese in Britain, 103.
} 
carrier of both physical disease and moral corruption. ${ }^{52}$ Sexual unease and 'deviation', disease and the eroticisation of dirt in the early twentieth century have been linked together by Seth Koven amongst others. ${ }^{53}$ Descriptions by anti-immigrant campaigners of migrants arriving in the United Kingdom rarely failed to mention the poor physical condition and disease-ridden aspect of the arrivals, and implied a similar moral deficiency. The South Wales Daily News of 1908 wrote 'There are educated, decent, clean living Chinamen but the majority live in indescribable squalor. They carry la misère with them - la misère which implies poverty, squalor, wretchedness, vice and many other things. ${ }^{54}$ Unlike a detached 'colonial' prejudice, abstract in form and fed by reports of imperial conquest and a settler elite in far-off lands, racist discourse against both Chinese and Jewish migrants stressed the harm immigrants were inflicting on their neighbours in urban areas of Britain itself. These domestic-based minorities were apparently uncontainable, impossible to segregate socially or sexually from 'English'/'white' society' as in the formally racially-stratified colonies of Australia and South Africa.

The ultimate fear expressed in Edwardian racist discourse was miscegenation, and few reports on the Chinese community during this period fail to mention relations between Chinese men and English women. Both Chinese and Jewish immigrants, through international diasporic networks, were also widely held to be heavily involved in prostitution rings. ${ }^{55}$ Contemporary racist literature stressed the sexual threat posed by 'aliens', particularly to young girls, for whom, it was widely claimed, Chinese men especially showed a particular proclivity; 'a certain type of bold, precocious girl' ${ }^{56}$ It was asserted that Chinese men were distributing opium-laced sweets to young girls, gave alcohol to children, and lured women into their laundries with flattery and gifts before seducing them. Herman Scheffauer in his Chinese in England wrote that:

\footnotetext{
${ }^{52}$ Garrard, The English and Immigration, 53.

${ }^{53}$ See Seth Koven, Slumming: Sexual and social politics in Victorian London, (Princeton: Princeton University Press 2006).

${ }^{54}$ Joanne M. Cayford, 'In Search of "John Chinaman”: Press Representations of the Chinese in Cardiff, 19061911 ' in Llafur, Journal of Welsh Labour History, vol. 5, no.4, 1991, 37-50 (40)

${ }^{55}$ See City of Liverpool Report of the Commission appointed by the City Council to inquire into Chinese Settlements in Liverpool, National Archives HO/45/11843/13947/15, 'Allegations have been made which would point to the fact of a number of Chinese laundries in the city being nothing less than brothels.' See also Edward J. Bristow, Prostitution and Prejudice: The Jewish Fight against White Slavery, 1870-1939, (Oxford: Clarendon Press 1982) and W.J Fishman, East End 1888: A year in a London borough among the labouring poor, (London: Gerald Duckworth \& Co. Ltd. 1988) 206

${ }^{56}$ Scheffauer, 'The Chinese in England', 477. See also Colin Holmes, John Bull's Island: Immigration \& British Society, 1871-1971, (Basingstoke: Macmillan Education Ltd 1988) 80
} 
Many tales were told me of the baleful part played by gifts of sweetmeats, necklaces and silk handkerchiefs made by Chinese to Englishwomen, of secret visits to laundries for a cup of tea... The passions of a voluptuous race are bound to express themselves in a foreign environment, and foreign women offer no obstacle, but rather, as most students of semi-civilised peoples will admit, an incentive. $^{57}$

Both Jews and Chinese were accused of purposefully setting out to morally corrupt 'English womanhood'. In England under the Jews, Joseph Banister wrote that '... No Jew is more of a hero among his fellow tribesmen than the one who can boast of having accomplished the ruin of some friendless, unprotected Christian girl. ${ }^{58}$ Banister describes the Jews as 'the most lecherous breed in existence, [who have] acquired such a vile reputation among working women. ${ }^{59}$

The Chinese male as sexual predator was also a common theme in contemporary literature. In the Thomas Burke story 'Tai Fu and Pansy Greers', in the Limehouse Nights series of stories, published in 1916, a sexual encounter between a Chinese man and an English woman was described thus: 'What he did to her in the blackness of the curtained room of his had best not be imagined... She came away with bruised limbs and body, with torn hair, and a face paled to death. ${ }^{60}$

Miscegenation was a particular obsession of Edwardian society, and the small, predominantly male Chinese community became a focus for this obsession, particularly in Liverpool and Cardiff. In a society still upholding a stratified racial hierarchy abroad, marriages between Chinese men and English women, and Anglo-Chinese children growing up in British towns and cities, seemed both dangerous and subversive of accepted racial interactions, symptomatic of a wider decline. For one Liverpool journal:

It is with a shock that one sees such names as Mary Chung or Norman Sing... It is the ambition of a Chinaman in this country to mate with an English girl... the propagation of half-bred Chinese and English in Liverpool is not a matter to be

\footnotetext{
${ }^{57}$ Scheffauer, 'The Chinese in England', 478

${ }^{58}$ Banister, England Under the Jews, 39

${ }^{59}$ Banister, England Under the Jews, 39

${ }^{60}$ Marek Kohn, Dope Girls: The Birth of the British Drug Underground, (London: Granta Books 1992) 58; Within the Limehouse nights another short story, 'The Chink and the Child', despite the title, contains a sympathetic Chinese character, Cheng Huan, who rescues a white girl from her sexually abusive father. See Forman, China and the Victorian Imagination, 198.
} 
treated lightly... Such a degraded type should not be allowed to grow up in our midst to be a source of contamination and further degradation for generations ahead. $^{61}$

These fears of miscegenation in British ports with comparatively large settled or transitory non-white male populations in the Edwardian period mark a key point in the conflation of domestic and colonial forms of racism. The children of these 'mixed marriages' were both British and non-white, and were not sojourners waiting for a berth on the next ship, but, just as with second or third generation Irish Catholics or Jews, here to stay. John Seed has documented the discrimination and difficulties encountered by the children of these 'mixed marriages' in the inter-war period. ${ }^{62}$ In 1901 a correspondent to Blackwood's Magazine concluded an article about Jewish/Chinese racial interactions in East London by wondering if '... the slums were to bring to birth a slit-eyed mongrel' - a diasporic Frankenstein's Monster, part-Chinese and part-Jewish. ${ }^{63}$ During the Edwardian period domestic racism began for the first time to centre on the issue, crucial in colonial racism, of skin colour, as well as on the cultural and religious prejudices which had been at the heart of contemporary anti-Irish and anti-Jewish discrimination.

Attitudes towards 'mixed marriages' involving Jews were more complex than the straightforward horror expressed by Sinophobic commentators on unions between Chinese men and English women. Indeed, for some writers Jewish 'clannishness', and the refusal to 'marry out' were proof of the inability of the Jewish immigrant population ever to successfully integrate. '... whereas all the others freely intermarry, talk, worship, eat with us, and fight for us, the stricter Jews... will do none of these things; they preserve their tribal customs... ${ }^{64}$ In the debate on national and racial decline, some suggested that 'Anglo-Saxon blood' could benefit from a 'Jewish infusion'. For the Liberal MP Sir Charles Dilke, speaking in parliament, 'Miserable as may be their [Russian Jews'] condition when they come here, they are not of a stock inferior to our own. They are of a stock which, when it mixes with our own in the course of years, goes rather to improve than to deteriorate the British race. ${ }^{65}$ Such sentiments were anathema to anti-Semites such as Joseph Banister. Banister's anti-Semitism

\footnotetext{
${ }^{61}$ Liverpool Courier December 1906 - quoted in Clegg, Fu Manchu and the 'Yellow Peril', 10.

${ }^{62}$ John Seed, 'Limehouse Blues: Looking for Chinatown in the London Docks, 1900-40' History Workshop Journal, no. 62, Autumn 2006 58-85 (67)

63 'Foreign Undesirables' in Blackwood's Magazine, No.MXXIV (London: William Blackwood and Sons February 1901) 279-289 (289)

${ }^{64}$ White, The Modern Jew, 140

${ }^{65}$ Feldman, 'The Importance of being English' 79
} 
was not based around religious faith, or an aversion to some element of Jewish culture or practice, but was racial, a belief that Jews were both implicitly and immutably inferior and dangerous by the nature of their being Jewish. On Jewish intermarriage, Banister wrote that:

Jewish blood, like that of other Oriental breeds, is loaded with scrofula... Mr Arnold White... has complained that they [the Jews] are unwilling to mingle their blood, and become assimilated with the people of the countries they honour with their presence... Owing to the tendency mentioned, it would be well if the Jew did object to mingle their blood with that of the Gentiles. ${ }^{66}$

For Banister the Jews were fundamentally an 'Asiatic', 'Oriental' ethnicity, whose presence was framed in the language of an infectious disease.

For all the racial invective aimed against Jews and Chinese by Banister and others, outbreaks of serious physical violence against either community were relatively rare in the Edwardian period. The areas with the highest Jewish settlement in Britain, East London, Leeds and Manchester, witnessed only sporadic violence, mainly between gangs of children and youths. The most serious anti-Semitic violence of the period took place in areas with small Jewish communities - Limerick in Ireland, where a Catholic priest, Fr Creagh, organised an antiJewish boycott, and the town of Tredegar in South Wales. Birkenhead witnessed anti-Chinese rioting in 1911 by several thousand men and women, but the most serious case occurred in Cardiff in the same year. What was the nature of the Jewish and Chinese communities' resident in these locations, and why did violence erupt in these particular local contexts?

Tredegar's Jewish community was small and well established, largely middle class, owning a number of local businesses. This was significant in that, as Anthony Glaser has noted, much of the violence of 1911 seemed directed at Jewish economic targets, shops rather than homes, local and accessible 'symbols of capitalism.' ${ }^{67}$ Tredegar also had a history of ethnic violence, with significant confrontations between locals and Irish labourers in $1882 .{ }^{68}$ The rioting of 1911 must be seen in the context of industrial unrest, rather than deep-seated anti-Semitic sentiment. The anti-Jewish attacks of that year were not to be repeated, at least in Tredegar. The Chinese communities in both East London and Cardiff were also long-established, with settlement from the 1870s, but unlike Tredegar's Jewish community, transient. There was

\footnotetext{
${ }^{66}$ Banister, England Under the Jews, 88-89

${ }^{67}$ Anthony Glaser, 'The Tredegar Riots of August 1911', in Ursula R.Q Henriques, The Jews of South Wales (Cardiff: University of Wales Press 2013) 151-176 (159)

${ }^{68}$ Glaser, 'The Tredegar Riots of August 1911', 155-156
} 
also a significant gap between wider popular perceptions of these areas and reality in the Edwardian period. Those intrepid explorers venturing into Limehouse's 'Chinatown' with expectations fed by the work of Sax Rohmer and others frequently expressed disappointment at the mundane state of affairs awaiting them. John Seed in 'Limehouse Blues' has discussed at length the gap between expectation and reality in Pennyfields and Limehouse Causeway. ${ }^{69}$ Even within these streets the Chinese population was in fact in a minority, and existed 'side by side with English working class families, pubs, shops and tradesmen and a multi-national population... 70 Seed has demonstrated the consistent over-estimation of the Chinese population of Limehouse. ${ }^{71}$ Cardiff too had a long-established if numerically small Chinese community. The racial violence in Cardiff had as its apparent catalyst resentment at Chinese sailors displacing other nationalities on British ships. Led by the locally notorious 'Captain' Tupper, this agitation soon descended into attacks on the wider Chinese community, with no connections to British shipping. On 20 July 1911 all but one of the twenty-two Chinese laundries were looted and burned. ${ }^{72}$ Specific economic and employment-based grievances spiralled into general ethnically-based attacks. This would be repeated in the riots of 1919. In an East End context, while there was undoubtedly English working class hostility towards Chinese settlement, framed in the language of invasion as described above, much of the sporadic violence in Limehouse was in fact brawling by transient sailors of varied nationalities. ${ }^{73}$

Both the anti-Jewish rioting in Tredegar, apparently sparked by youths and children throwing stones at a Jewish shop, ${ }^{74}$ and the anti-Chinese violence in Cardiff, which broke out during the seamans' strike, soon turned into a general campaign of looting, and attacks on the police, which in Cardiff assumed an ethnic aspect when Metropolitan officers from London were drafted in to restore order. Police were greeted with rioters and onlookers shouting 'Go back to London you fucking bastards', one woman arrested for throwing a bottle claimed 'It was meant for them cockney bastards'. ${ }^{75}$ The sacking and arson of the Chinese laundries of Cardiff, however, must be seen in the context of a prolonged campaign against the Chinese in the city by the National Union of Seamen and Firemen. Joanne M. Cayford has located the

\footnotetext{
${ }^{69}$ Seed, 'Limehouse Blues: Looking for Chinatown in the London Docks, 1900-40

${ }^{70}$ Seed, 'Limehouse Blues: Looking for Chinatown in the London Docks, 1900-40', 67-68

${ }^{71}$ Seed, 'Limehouse Blues: Looking for Chinatown in the London Docks, 1900-40', 68

${ }^{72}$ Auerbach, Race, Law and "The Chinese Puzzle" in Imperial Britain, 55-56

${ }^{73}$ Auerbach, Race, Law and "The Chinese Puzzle" in Imperial Britain, 56-57

${ }^{74}$ The Times, 21 August 1911.

${ }^{75}$ May, 'The British Working Class and the Chinese' 79-80
} 
anti-Chinese riots of 1911 in the context of the severe industrial unrest in South Wales during this period, and Tredegar too must be viewed as a manifestation of a wider breakdown in labour relations and law and order in the 1911-12 period. ${ }^{76}$ The riots of 1911 were a harbinger of future ethnic violence, in the war years and beyond, including the anti-Jewish draft riots that broke out in East London and Leeds in 1916, violence against Chinese in Poplar in July of the same year, and the riots of 1919, directed against non-white sailors and residents of British ports, which rapidly spread across the country and resulted in serious loss of life. ${ }^{77}$ This ethnic violence must be seen in the contemporary current of extreme hypernationalism, social displacement and economic insecurity.

\section{Conclusion}

Anti-Semitic and Sinophobic racism in the Edwardian period marked a key juncture in the development of racial prejudice in the United Kingdom. In the decade before the First World War fears of miscegenation, of the intrusion of foreign elements into the British racial body and of the diluting of racial stock, ceased to be solely a matter of concern for a colonial ruling class in far-off territories, and became an issue on the streets of urban Britain. Edwardian paranoia over mixed marriages and conjugal relations between Chinese men and English women developed in the inter-war period into a racist hostility towards white/non-white interactions in British towns and cities. The riots of 1919, in which non-white men and white women keeping company were attacked by mobs, were an early manifestation of this extreme racial angst. One article published in the Daily News in October 1920 entitled 'Yellow Evil in East End' wrote of 'young English girls' committing 'moral and physical suicide' by associating with Chinese men. ${ }^{78}$

The Jewish or Chinese 'puppet master', the criminal Moriarty figure, also continued to be a stock type of interwar and post-war racism and racist literature. 'Brilliant' Chang, an East London gangster of the 1920s, was portrayed in the popular press as a real-life Fu Manchu, instead of the rather mundane racketeer and smuggler he actually was. ${ }^{79}$ The Jewish "super criminal' was also a familiar figure in inter-war detective fiction, in the work of Agatha Christie, 'Sapper' and Edgar Wallace, who described the East End Jewish villain of one story

\footnotetext{
${ }^{76}$ See Cayford, 'In Search of "John Chinaman"'. A contemporary article in the Merthyr Express of 9 September 1911 blamed the Tredegar violence on the 'spirit of Socialism'

${ }^{77}$ See Jacqueline Jenkinson, Black 1919: Riots, Racism and Resistance in Imperial Britain, (Liverpool: Liverpool University Press 2009)

78 'Yellow Evil in East End', Daily News, 4 October 1920

${ }^{79}$ See Kohn, Dope Girls
} 
as a 'Dangerous Reptile'. ${ }^{80}$ The 'International Jew' as power behind the scenes remained and remains a familiar figure in anti-Semitic literature. ${ }^{81}$

Anti-Semitism, in the Edwardian period primarily a domestic form of racism, assumed a colonial nature in the inter-war years, during the British Mandate in Palestine. From the mid1930s Britain found itself fighting a counter-insurgency campaign against both Jewish and Arab guerilla groups. The 1947 anti-Semitic rioting across Britain, the most serious since Tredegar, was directly linked with events in Palestine. 'Yellow peril' paranoia after the First World War also evolved, from the early 1930s until 1945 shifting its focus in Britain and America towards an aggressive and militaristic Japan, before switching back to China after the Communist Revolution in 1949. Sexton Blake was still combating Chinese 'super villains' on BBC radio at the end of the 1960s.

The Edwardian period witnessed the first example of peacetime legislation that explicitly limited entry into the United Kingdom, and the use of anti-immigrant rhetoric, on all political sides, for electoral gain. It also saw the emergence of anti-immigrant pressure groups such as the BBL, with an explicit programme of anti-immigrant activity advocating border controls and repatriation, groups which made use of the language of invasion and racial paranoia. Aimed in this period primarily at Jews and Chinese, the rhetoric of Edwardian racism, and the biological anti-Semitism of writers such as Joseph Banister, would be adopted and expanded upon by the fascist movements of the inter-war and post-Second World War eras, from Leese's Imperial Fascist League and Mosley's British Union of Fascists, up to the National Front and other organisations. The fixation on the dangers of racial mixing described above intensified during the first wave of immigration from the New Commonwealth after the Second World War, and became a feature of the rhetoric of neofascist and anti-immigrant campaign groups from the 1950s onwards. This marked the final confluence of domestic-based, primarily economic and social, prejudice on the one hand, and an abstract colonial racism on the other, that had accelerated at the beginning of the twentieth century. These post-1945 neo-fascist groups made use of both old and new 'others' as targets, maintaining a virulent anti-Semitism, but with invective primarily aimed at South Asian and

\footnotetext{
${ }^{80}$ See Edgar Wallace, The Mind of Mr J.G Reeder, (London: Hodder and Stoughton 1925) 'The Green Mamba'

${ }^{81}$ See John Buchan, The Thirty-Nine Steps (London: Hodder and Stoughton 1986 (1915)) 18 - Quote from the character Franklin Scudder: 'But if you're on the biggest kind of job and are bound to get to the real boss, ten to one you are brought up against a little white-faced Jew in a bath-chair with an eye like a rattlesnake. Yes, sir, he is the man who is ruling the world just now.'
} 
Prejudice and paranoia

Caribbean migrants, combining the rhetoric of the old, redundant imperial racism with new domestic manifestations of prejudice.

Word Count -8453 